\title{
A study on the surface characteristics of diamond wire-sawn silicon wafer for photovoltaic application
}

\author{
Kyoung-Hee Lee ${ }^{\dagger}$ \\ Department of Biochemical Engineering, Dongyang Mirae University, Seoul 152-714, Korea
}

(Received September 30, 2011)

(Revised October 21, 2011)

(Accepted November 4, 2011)

\begin{abstract}
Most of the silicon cutting methods using the multi-wire with the slurry injection have been used for wafers of the crystalline solar cell. But the productivity of slurry injection cutting type falls due to low cutting speeds. Also, the direct contact with the metal wire and silicon block increases the concentration of metallic impurities in the wafer's surface. In addition, the abrasive silicon carbide ( $\mathrm{SiC}$ ) generates pollutants. And production costs are rising because it does not re-use the worn wire. On the other hand, the productivity of the cutting method using the diamond coated wire is about 2 times faster than the slurry injection cutting type. Also, the continuous cutting using the used wire of low wear is possible. And this is a big advantage for reduced production costs. Therefore, the cutting method of the diamond coated wire is more efficient than the slurry injection cutting technique. In this study, each cutting type is analyzed using the surface characteristics of the solar wafer and will describe the effects of the manufacturing process of the solar cell. Finally, we will suggest improvement methods of the solar cell process for using the diamond cutting type wafer.
\end{abstract}

Key words Silicon, Silicon wafer, Diamond coated wire, Diamond wire saw, Surface roughness, Metal impurity, Damage depth, Texturing

\section{다이아몬드 코팅 와이어로 가공된 태양전지용 실리콘 웨이퍼의 표면 특성에 관 한 연구}

\section{이경희 ${ }^{\dagger}$}

동양미래대학 생명화공과, 서울, 152-714

(2011년 9월 30일 접수)

(2011년 10월 21일 심사완료)

(2011년 11월 4일 게재확정)

요 약 현재 결정질 태양전지에서 웨이퍼 가공은 대부분 슬러리 분사 방식의 다중 와이어를 이용한 방법이 사용되고 있다. 이와 같은 슬러리 분사 방식의 웨이퍼 가공은 가공속도가 낮아 생산성이 떨어지는 단점이 있을 뿐만 아니라 금속 재 질의 와이어와 실리콘 블록의 직접적인 마찰에 의하여 웨이퍼 표면의 금속 불순물에 의한 오염이 발생되는 단점이 있다. 뿐만 아니라 와이어와 실리콘 블록간의 직접적인 마찰로 인하여 와이어가 빨리 마모되며, 이로 인하여 일회성의 와이어를 사용하게 되면서 제조원가는 상승하게 된다. 반면에 다이아몬드 입자가 코팅된 와이어를 이용하여 실리콘 웨이퍼를 가공하 게 되면, 가공속도가 기존 슬러리 분사방식보다 빠르며, 공정진행에 따른 와이어의 마모율이 적어 와이어의 재사용에 의한 제조원가 절감이 가능하다. 따라서 이와 같은 다이아몬드 입자가 코팅된 와이어를 이용하여 가공하는 기술은 슬러리 분사 방식에 비하여 더 효율적이라 할 수 있다. 본 연구에서는 슬러리 분사방식으로 가공된 웨이펴와 다이아몬드 코팅된 와이어 로 가공된 웨이퍼의 표면특성에 대하여 분석하고 셀 공정에 영향을 미치는 것에 대하여 설명하고자 한다. 또한, 다이아몬 드 와이어로 가공된 웨이퍼를 활용하기 위한 셀 공정의 개선방향에 대하여 제안하고자 한다.

\footnotetext{
Corresponding author

Tel: +82-2-2610-1813

Fax: +82-2-2610-1858

E-mail: lkh@dongyang.ac.kr
} 


\section{1. 서 론}

현재의 태양전지 분야의 웨이퍼링 기술은 슬러리 분사 방식의 다중 와이어 방법이 사용되고 있다. 이러한 방법 은 실리콘 블록에 연마제가 포함된 슬러리를 주입하면서 부드러운 금속의 와이어를 이용하여 박형으로 절단하는 방법이다 $[1,2]$. 주입되는 슬러리는 일반적으로 유체상태 의 Polyethylene glycol(PEG)와 미세한 입자형태의 연마 용 Silicon Carbide( $\mathrm{SiC}$ )가 주입된다. Silicon Carbide의 미세한 입자들은 실리콘을 박형의 웨이퍼 상태로 절단하 게 된다. 그러나 이와 같은 웨이퍼링 공정은 가공 속도 가 비교적 느리며, 금속 와이어와의 직접적인 마찰로 인 하여 웨이퍼의 금속 오염 발생 등의 문제가 발생된다. 뿐만 아니라 공정중 주입하는 슬러리로 인하여 와이어는 단회 사용 후 반드시 오염 인자를 제거해 주어야 하는 불편함이 있다. 이와 같은 문제에 대한 대안으로 최근 다이아몬드가 코팅된 와이어를 이용하여 절단하는 공정 이 개발되고 있다 $[3,4]$. 다이아몬드가 코팅된 와이어를 사용한 웨이퍼링 공정은 기본 장치는 슬러리 분사 방법 의 장치와 유사한 다중 와이어 절단 방법이 사용되지만, 연마용 슬러리는 냉각수로 대체되고 와이어 표면에 미세 한 다이아몬드 입자가 코팅된 와이어가 사용된다. 이와 같은 다이아몬드 코팅 와이어를 이용한 웨이퍼링 공정의 특징은 가공속도의 향상을 통한 생산성 증가, 냉각수의 손쉬운 재사용 (대부분 실리콘 가공 부산물의 경우 고압 분사 냉각수에 의하여 쉽게 제거됨.), 낮은 와이어 마모 도로 인한 재사용(다이아몬드 입자가 코팅되어 있기 때 문에 슬러리 웨이퍼링의 금속 와이어를 사용할 때보다 더 낮은 마모 특성을 가지고 있다.) 등의 많은 장점들을 가지고 있다. 그러나 이러한 새로운 기술이 공정에 적용 되기 위해서는 태양전지 생산라인에 많은 변화를 주지 않아야 한다. 본 연구는 슬러리 분사 방식의 가공 웨이 퍼와 다이아몬드 코팅 와이어를 이용한 가공 웨이퍼 간 의 표면 특성에 대하여 고찰하고자 한다.

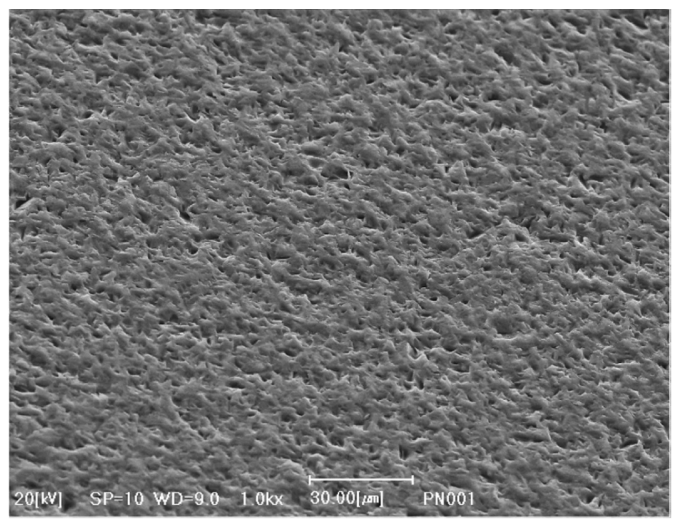

\section{2. 실험방법}

실리콘 블록(면적 $156 \times 156 \mathrm{~mm}^{2}$, 길이 $400 \mathrm{~mm}$ )을 한가지는 슬러리 분사 방식으로 가공하고, 또 다른 한가 지는 다이아몬드 코팅 와이어를 이용한 방식으로 $200 \mu \mathrm{m}$ 두께의 웨이퍼로 가공하였다. 각각의 공정을 통해서 가 공된 웨이퍼에 대하여 SEM, ICP-MS, Saw Damage Depth, 및 텍스쳐링 분석을 통하여 공정에 따른 비교 분 석을 진행하였다.

SEM-EDX는 CX-100S를 사용하여 그 형상을 분석하 였다. 또한 웨이퍼 표면의 특성을 살펴보기 위하여 Saw Damage Depth를 측정하였으며, Angle Lapping Machine (Model명: R90)과 Etching 용 Acid Hood를 이용하여 샘플의 전처리를 하여 광학현미경으로 그 크기를 측정하 였다. 웨이퍼의 표면 금속불순물 농도는 ICP-MS를 이용 하여 측정하였으며, ELAN DRC-2를 이용하였다. 기판 의 텍스쳐링 평가를 위하여 슬러리 분사방식 및 다이아 몬드 코팅 방식의 두 가지 절단 방법으로 가공된 웨이퍼 를 4 인치 크기로 샘플링하여 금속불순물 제거 및 표면 산화막 제거를 위한 $10 \% \mathrm{HCl}$ 에 10 분간 세정을 실시한 이후 $\mathrm{NaOH} 3 \%$, IPA $6 \%$, DIW 혼합용액을 80 도 온 도에서 25 분간 텍스쳐링을 실시하였다.

\section{3. 결 과}

\subsection{SEM 형상 분석}

각 타입의 웨이퍼에서 샘플링하여 분석하였으며, Fig. 1 에 웨이퍼의 표면을 나타내었다. 슬러리 분사방식으로 가공한 웨이퍼의 표면(Fig. 1a)의 경우 와이어의 진행방 향을 확인하기 어려운 거친 표면특성이 관찰된다. 반면 다이아몬드 코팅된 와이어를 이용하여 가공한 웨이퍼는 다이아몬드 입자의 가공에 의하여 생성된 평행한 그루브

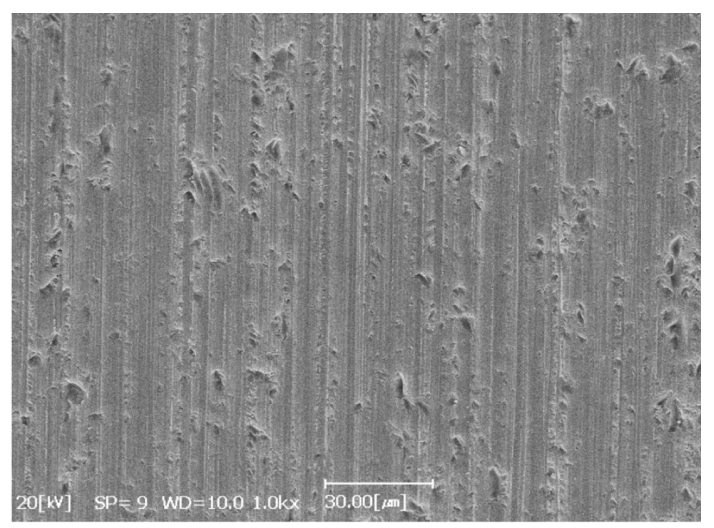

Fig. 1. SEM images (a) Slurry sawn wafer (b) Diamond wire-sawn wafers measured perpendicularly to the wire direction. 
가 관찰된다. 이러한 그루브는 부분적으로 뜯겨있는 형 태이다. 다이아몬드 와이어를 이용한 가공 웨이퍼에서는 다이아몬드 입자가 표면을 가공하면서 두꺼운 Oxide층 이 생길 가능성이 있다[5].

\section{2. 웨이퍼 표면 거칠기 비교}

웨이퍼의 거칠기를 비교하는데 두 샘플의 몇 가지 다 른 점이 있다. 슬러리 타입의 가공 웨이퍼는 거칠기 측 정 방향에 큰 영향을 보여주지 않는 반면 다이아몬드 와 이어를 이용한 가공 웨이퍼는 표면의 형태가 강한 이방 성을 나타낸다. 뿐만 아니라 슬러리 웨이퍼의 거칠기는 와이어의 마모에 의하여 와이어의 진출부로 갈수록 웨이 퍼의 두께가 증가하는 경향을 나타낸다. 반면에 다이아 몬드 와이어로 가공된 웨이퍼의 경우 다이아몬드 입자로 인한 와이어 마모가 발생되지 않아 와이어 경로에 따른 변화는 거의 없다. 하지만 웨이퍼 스케일에서 다이아몬 드 와이어로 가공된 웨이퍼의 표면은 슬러리 가공 웨이 퍼와 비교하면 다이아몬드 와이어를 이용하여 가공한 웨 이퍼에서와 유사한 표면 거칠기 값을 나타낸다. 다이아 몬드 와이어를 이용한 가공 웨이퍼는 와이어가 전,후진 하면서 가공하고 이에 따라 Feed 속도와 와이어 방향 변화로 인하여 웨이퍼 표면 굴국이 만들어진다. 하지만, 그 표면 거칠기의 크기는 Table 1 에 나타낸 바와 같이 슬러리 분사방법의 웨이퍼와 다이아몬드 코팅 와이어를 이용하여 가공한 웨이퍼 간의 표면 거칠기 차이는 크지

Table 1

Roughness of (a) Slurry sawn (b) Diamond wire-sawn wafers measured perpendicularly to the wire direction

[unit: $\mu \mathrm{m}$ ]

\begin{tabular}{lll}
\hline & Slurry sawn wafer & Diamond wire sawn wafer \\
\hline $\mathrm{Ra}$ & 0.265 & 0.289 \\
$\mathrm{Rz}$ & 1.007 & 1.021 \\
\hline
\end{tabular}

않다.

\subsection{Damage depth 분석}

앞서 웨이퍼 표면의 거칠기 비교에서 다이아몬드 코팅 와이어를 이용한 웨이퍼가 슬러리 분사방식의 웨이퍼에 비하여 큰 값으로 평가되었으나, $\left(\mathrm{R}_{\mathrm{a}, \mathrm{diamond}} 0.289 \mu \mathrm{m}\right.$, $\left.\mathrm{R}_{\mathrm{a}, \text { slurry }} 0.265 \mu \mathrm{m}\right)$ 와이어 가공에 의한 웨이퍼 내부의 Damage에 대한 비교를 위해 Damage depth를 측정하여 그 결과를 Fig. 2에 나타내었다. 슬러리 타입으로 가공 된 웨이퍼의 경우 Damage depth가 $7.2 \mu \mathrm{m}$ 수준으로 측 정되었으며, 다이아몬드 타입으로 가공된 웨이퍼의 경우 Damage depth가 $4 \mu \mathrm{m}$ 수준으로 측정되었다. 이는 가공 공정에 따라 다를 수 있으나, 일반적으로 슬러리 타입과 다이아몬드 타입 웨이퍼의 Saw damage depth는 다이아 몬드 타입의 웨이퍼가 더 낮은 Damage depth를 갖고 있음을 확인할 수 있었다.

\section{4. 표면 금속 불순물}

일반적으로 금속불순물과 태양전지 효율과는 상관관계 가 있음이 알려져 있으며[6], 금속불순물을 최소화하는 공정 개발은 필수적이다. 웨이퍼의 표면 금속불순물 오 염은 절단 공정에서 야기되며, 웨이퍼의 클리닝 공정에 서 제거된다. 하지만, 많은 금속 불순물 중에서 $\operatorname{Iron}(\mathrm{Fe})$, Copper $(\mathrm{Cu})$ 원소는 와이어를 구성하는 재질로써 웨이퍼 의 표면에 잔여물로 남게 되며, 시간이 지남에 따라 웨 이퍼 내부로 침투되는 특성이 있어 이후 웨이퍼 세정 공 정에서 이들 원소를 제거하기 쉽지 않다. 이러한 특성은 대부분 슬러리 와이어 가공방법에서 나타나게 되며, 다 이아몬드가 코팅된 와이어는 일반적으로 와이어 표면에 다이아몬드를 부착한 후 $\mathrm{Nickel}(\mathrm{Ni})$ 층으로 도금하게 되 면서 실제 가공된 웨이퍼와 직접적으로 마찰되는 부분은 다이아몬드 입자와 $\mathrm{Ni}$ 층이다. 따라서, Table 2에서 볼
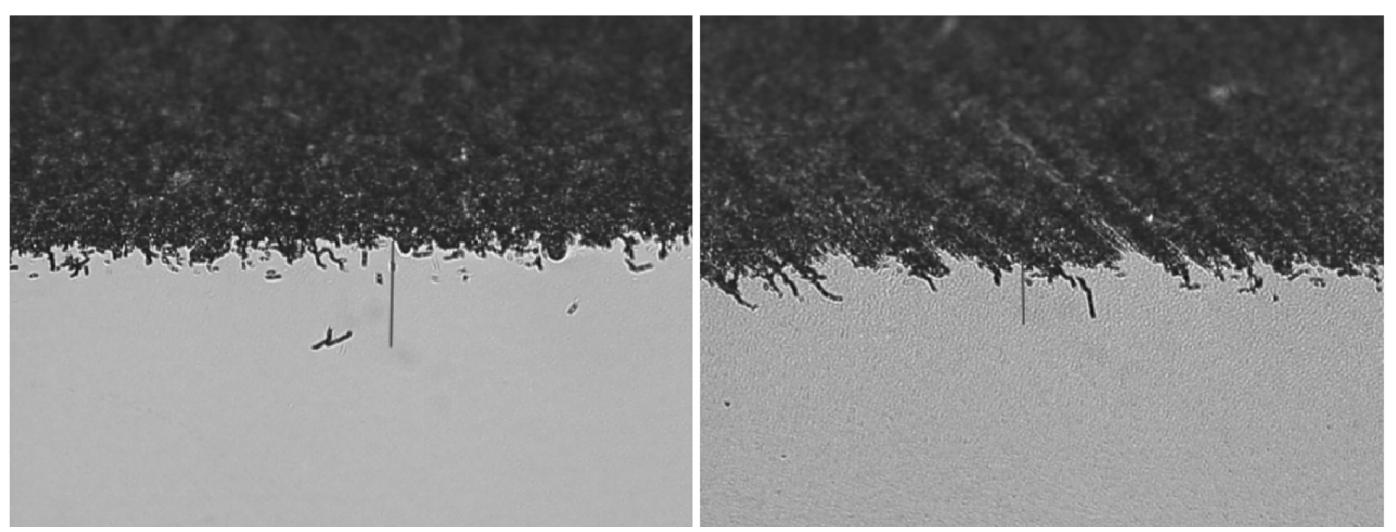

Fig. 2. Damage depth (a) Slurry sawn wafer $(7.2 \mu \mathrm{m})$ (b) Diamond wire-sawn wafer $(4 \mu \mathrm{m})$. 
Table 2

Surface metallic impurities of the Slurry sawn and Diamond wiresawn wafer

\begin{tabular}{lll} 
& & [unit: atoms $\left./ \mathrm{cm}^{2}\right]$ \\
\hline & Slurry sawn & Diamond wire sawn \\
\hline Fe concentration & $6.15 \mathrm{E}+15$ & $1.07 \mathrm{E}+12$ \\
Cu concentration & $9.84 \mathrm{E}+13$ & $5.61 \mathrm{E}+09$ \\
\hline
\end{tabular}

수 있듯이 두 가지 타입의 공정에서 가공된 웨이퍼의 금 속 불순물 농도는 많은 차이를 나타내며, 다이아몬드 웨 이퍼에서 금속 불순물의 농도가 훨씬 적음을 알 수 있다. 이는 향후 태양전지의 효율에도 영향을 미칠 수 있다.

\section{5. 텍스쳐링 형상 비교}

태양전지 제조의 첫번째 공정은 광 흡수를 증가하는 텍스쳐링 공정이다. 단결정 웨이퍼는 이방성 에칭에 의 한 식각으로 웨이퍼의 표면을 피라미드 형태로 식각하여 광 흡수를 증가하게 된다. 슬러리 가공 웨이퍼에서는 $\mathrm{KOH}, \mathrm{IPA}, \mathrm{DIW}$ 혼합용액에서 약 25분간 텍스쳐링을 진행하며, 이 때 빛을 흡수하기에 충분한 $6 \sim 7 \mu \mathrm{m}$ 크기 의 피라미드 형태 표면을 나타낸다. 하지만, 다이아몬드 가공된 웨이퍼의 경우는 동일한 시간으로 에칭을 진행할 시 충분한 에칭이 진행되지 않는 것을 확인할 수 있었으 며, 동일한 표면 특성을 나타내기 위해서는 에칭 공정조 건 및 에칭 시간 등에 대한 최적화를 진행해야만 한다. Fig. 3에 각각의 타입에서 최적화한 에칭 공정조건을 통 한 Textured 웨이퍼의 SEM 사진을 나타내었다. 그림에 서 볼 수 있듯이 각각의 타입에서 피라미드 크기와 형태 는 유사함을 알 수 있었으며, 이는 슬러리 타입의 웨이 퍼와 다이아몬드 타입의 웨이퍼간 비정질 결정화막과 표 면 산화막 등에 의하여 식각 속도가 다를 수 있으며, 태 양전지용 웨이퍼의 에칭에 대한 텍스쳐링 최적화가 진행

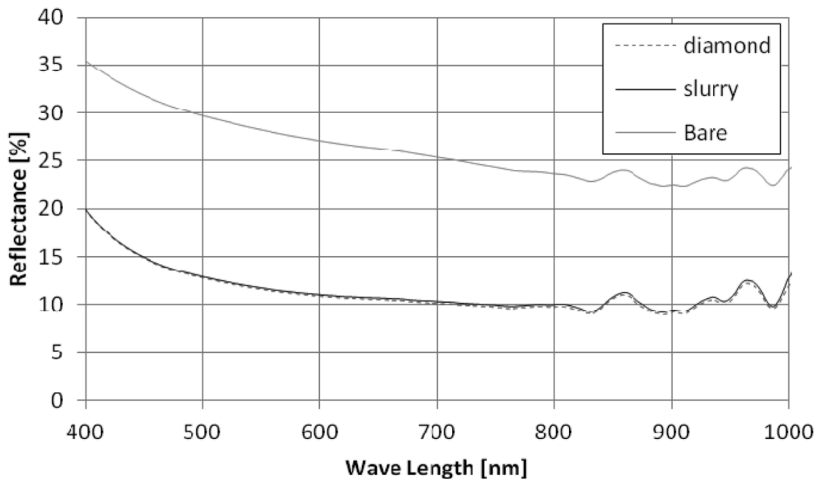

Fig 4. Reflectance of textured wafers (The reflectance of the bare wafer is $25 \%$ and reflectance of the slurry sawn wafer and diamond coated wafer is $11 \%$ ).

된다면 동일한 텍스쳐링 특성을 구현할 수 있음을 알 수 있다. Fig. 4에서 볼 수 있듯이 텍스쳐링 이후 슬러리 타입의 웨이퍼와 다이아몬드 타입의 웨이퍼의 반사도는 약 $11 \%$ 로 동일한 특성을 나타내고 있으며, 슬러리 타 입의 웨이퍼와 다이아몬드 타입의 웨이퍼는 태양전지 제 작 공정에서 광흡수 특성이 유사함을 알 수 있다.

\section{4. 고 찰}

슬러리 분사를 통하여 가공된 웨이퍼와 다이아몬드가 코팅된 와이어를 이용하여 가공한 웨이퍼의표면은 SEM 이미지를 통하여 알 수 있듯이 슬러리 분사를 통하여 가 공된 웨이퍼의 표면은 부드러운 와이어와 연마제의 마찰 을 통하여 실리콘 블록을 가공하게 되며, 이 때 연마제 입자들이 실리콘을 제거하면서 각종 결함들을 발생시킨 다. 다이아몬드가 코팅된 와이어를 이용하여 가공한 웨 이퍼는 수평 방향으로 패인 홈들이 관찰되는 것과 같이 실리콘 절단 프로세스는 기존의 슬러리 타입과는 상이하
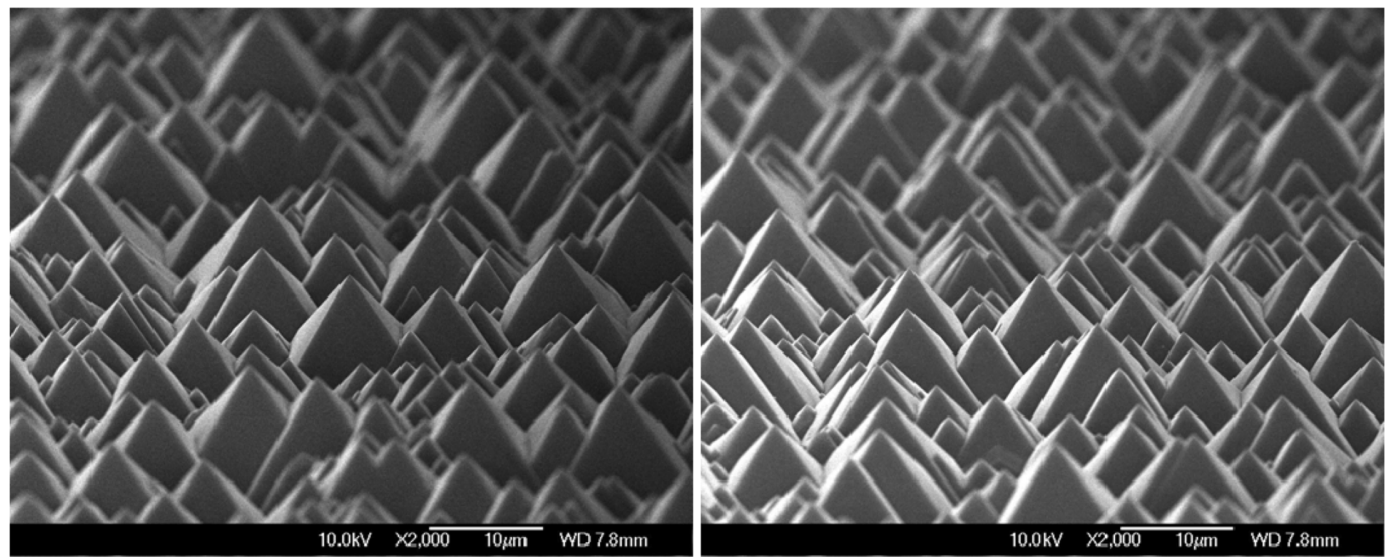

Fig. 3. SEM Images of textured wafers (a) Slurry sawn (b) Diamond wire-sawn. 
다. 이것은 다이아몬드 입자가 실리콘 블록과 직접적인 마찰을 통하여 가공되며, 표면에 단방향의 긁힘 특성이 나타나게 된다. 하지만, 다이아몬드 와이어를 이용하여 가공한 웨이퍼와 슬러리 방법으로 가공한 웨이퍼의 표면 의 거칠기는 비슷한 크기를 나타낸다. 또한, 가공방법에 따라 형성되는 표면으로부터 크랙 길이를 Damage Depth로 나타낼 수 있으며, 그 측정값을 비교한 결과 유 사한 크기를 나타냄을 알수 있었으며, 오히려 부분적으 로 다이아몬드 와이어를 이용한 웨이퍼에서 더 작은 값 을 확인할 수 있었다. 이는 가공이 웨이퍼에 미치는 응 력이 동등한 수준 또는 다이아몬드 웨이퍼에서 적게 측 정되고 있음을 알 수 있다. 다이아몬드 와이어를 사용하 는 공정의 가장 큰 장점중의 하나는 가공 속도 향상에 의한 생산성 향상을 꾀할 수 있다는 것이다. 다이아몬드 가 코팅된 와이어로 실리콘 블록을 절단 시 슬러리 분사 방법에 비하여 2 배 가까이 빠르게 절단할 수 있다. 다만, 빠른 가공속도에 의하여 발생되는 열은 DIW 계열의 쿨 런트로 제거해야만 한다. 이와 같이 빠른 가공을 통하여 발생된 열로 인하여 웨이퍼 표면에 더 두꺼운 Oxide 층 을 형성하며, 다이아몬드 입자의 긁힘에 의하여 형성된 웨이퍼 표면의 비정질 층과 함께 에칭시의 마스크 역할 을 하게 된다. 이러한 특성 때문에 태양전지 제조시 슬 러리 분사방식의 가공 웨이퍼와는 상이한 별도의 최적화 된 텍스쳐링 공정이 필수적이다. 다이아몬드 와이어를 사용하는 공정의 또한가지의 장점은 고품질 웨이퍼 제조 가 가능하다는 것이다. 일반적으로 태양전지용 기판에서 금속불순물의 농도가 높을수록 효율은 저하된다는 보고 가 있으며, 다이아몬드 와이어는 금속와이어와 실리콘 블록과의 직접적인 마찰을 피하여 금속불순물의 농도를 최소화 시킬 수 있으며, 더 양호한 특성의 금속불순물 농도의 제품을 만들 수 있다. 특히, 웨이퍼 내부로 침투 하는 $\mathrm{Fe}, \mathrm{Cu}$ 원소의 경우 일정량 미만으로의 농도 관리 가 필수적이며, 슬러리 분사방식의 가공 공정을 적용할 시 금속불순물 제거를 위하여 세정액을 자주 교체해야 하는 단점이 있는데 비하여 다이아몬드 와이어로 가공한 웨이퍼의 경우 금속 불순물이 낮아 세정액 교체 주기가 길어지는 장점이 있다. 마지막으로 다이아몬드 와이어 절단 웨이퍼는 슬러리 절단 웨이퍼 보다 TTV 특성이 더 좋아 태양전지 생산라인에 더 안정적일 수 있으며, 실제로 웨이퍼의 두께가 감소하면 감소할수록 $\mathrm{TTV}$ 는 점점 더 중요한 요소가 되어가고 있다. 다이아몬드가 코 팅된 와이어는 다이아몬드 입자가 와이어의 마모를 막아 주기 때문에 와이어가 천천히 마모되면서 훨씬 더 좋은 TTV 특성을 갖는 웨이퍼를 생산할 수 있다.

\section{5. 결 론}

본 연구에서는 다이아몬드 와이어로 자른 웨이퍼와 슬 러리 와이어로 자른 웨이퍼의 표면 특성이 근본적으로 다르다는 것을 보여주고 있다. 하지만, 텍스쳐링 공정을 진행하면서 웨이퍼 표면의 텍스쳐링 이후 형성된 피라미 드 크기에 비하여 훨씬 작은 수준이기에 표면 스크래치 는 큰 문제가 되지 않으며, 에칭하는 동안 마스크 역할 을 하는 비정질 실리콘의 존재는 에칭 프로세스의 최적 화를 필요로 하게 한다. 이는 에칭 프로세스 최적화(에 칭용액의 농도변경 또는 에칭시간 증가)를 통하여 극복 가능하다. 최적화된 에칭 프로세스로 만들어진 텍스쳐링 웨이퍼는 슬러리 타입이나 다이아몬드 타입이나 동일한 형상을 나타내며, 셀 제작에 있어서 동일한 특성을 갖는 웨이퍼로서 기능을 할 수 있을 것이라 사료된다. 이것은 태양전지 생산라인에 큰 변화없이 우수한 품질의 태양전 지를 생산하는데 다이아몬드 와이어가 효과적으로 사용 될 수 있을 것임을 나타내며, 다이아몬드 코팅된 와이어 가 절단매체로 사용 가능함을 나타내고 있다.

\section{감사의 글}

본 연구는 2010학년도 동양미래대학 학술연구사업의 지원에 의해 이루어졌습니다.

\section{참 고 문 헌}

[1] H.J. Moller, "Basic mechanisms and models of multiwire sawing", Adv. Eng. Mat. 6(7) (2004) 501.

[2] M. Bhagavat, V. Prasad and I. Kao, "Elasto-hydrodynamic interaction in the free abrasive wafer slicing using a wiresaw: modeling and finite element analysis", Journal of Tribology 122(2) (2000) 394.

[3] P. Tso, B. Yan and C. Lo, "Study on thin diamond wire slicing with taquchi method", Materials Science Forum Vols 505-507 (2006) 1219.

[4] R. Gassilloud, C. Ballif, P. Gasser, G. Buerki and J. Michler, "Deformation mechanisms of silicon during nanoscratching", Phys. Stat. Sol. (a) 202(15) (2005) 2858.

[ 5 ] A. Bidiville, et al., "Diamond wire-sawn silicon wafers - from the LAB to the cell production", $24^{\text {th }}$ European Photovoltaic Solar Energy Conference (2009) 1400.

[6] Davis Jr. J et al., "Impurities in solar cells", IEEE Trans. Electron Devices Ed-27 (1980) 677. 